\title{
PHYSICAL EDUCATION CLASSES AND INCLUSION OF CHILDREN WITH DISABILITY: BRAZILIAN TEACHERS' PERSPECTIVES
}

\author{
A AULA DE EDUCAÇÃO FÍSICA E A INCLUSÃO DA CRIANÇA COM \\ DEFICIÊNCIA: PERSPECTIVA DE PROFESSORES BRASILEIROS
}

\author{
CLASES DE EDUCACIÓN FÍSICA E INCLUSIÓN DE NIÑOS CON \\ DISCAPACIDAD: PERSPECTIVAS DE LOS MAESTROS BRASILEÑOS
}

\author{
Maria Luíza Tanure Alves*, Jalusa Andreia Storch*, Gabriela Harnisch*, \\ Aline Miranda Strapasson*, Otávio Luis Piva da Cunha Furtado*, \\ Lauren Lieberman**, José Júlio Gavião de Almeida*, Edison Duarte*
}

\section{Keywords:}

Physical Education.

Educational

inclusion.

Special education.

Disabled children.
Abstract: This study analyzed Physical Education teachers' concept of inclusion and determined positive and negative aspects of inclusion in their classes. Interviews were conducted with 18 Physical Education teachers working in Brazilian public schools. Data collected were examined by content analysis to search for emerging themes. The findings showed that inclusion was understood as participation and learning for all children rather than only for those with disabilities. Team sports were pointed as the main challenge for the inclusion of students with disability. Initial and continuing education programs for teachers need to target effective pedagogical practices to promote inclusion, leading to restructuring Physical Education teachers' training.
Palavras chave: Educação Física. Inclusão Educação especial. Crianças com deficiência. educacional.

Resumo: 0 estudo teve como objetivo analisar o conceito de inclusão dos professores de Educação Física e determinar os aspectos positivos e negativos em suas aulas. Foram realizadas entrevistas com 18 professores de Educação Física que trabalham em escolas públicas brasileiras. Os dados coletados foram analisados utilizando-se o método de análise de conteúdo, em busca de temas emergentes. Os resultados mostraram que a inclusão é compreendida pelos professores como participação e aprendizagem para todas as crianças e não apenas para aqueles com deficiência. Os esportes coletivos foram relatados como o principal desafio para a inclusão de alunos com deficiência. Programas de formação inicial e de capacitação continuada para os professores precisam propor práticas pedagógicas eficazes para promover a inclusão, levando a reestruturação da formação de professores de Educação Física.

Palabras clave: Educación física. Propensión (Educación). Educación especial. Niños con discapacidad.
Resumen: Los objetivos de este estudio fueron analizar concepto de inclusión profesores de educación física 'y determinar los aspectos positivos y negativos de la inclusión en sus clases. Se realizó una entrevista con 18 profesores de educación física que trabaja en las escuelas públicas brasileñas. Los datos recogidos fueron analizados utilizando el método de análisis de contenido, búsqueda de temas emergentes. Los resultados mostraron que la inclusión se entiende como la participación y el aprendizaje de todos los niños y no sólo para las personas con una discapacidad. Los deportes de equipo se informaron como un reto importante para la inclusión de los estudiantes con discapacidad. los programas de educación inicial y continua para los profesores tienen que orientar las prácticas pedagógicas efectivas para promover la inclusión, dando lugar a la reestructuración de la formación de profesores de educación física.
*UNICAMP. Campinas, SP, Brasil. E-mail: malu@fef.unicamp.br, jalusastorch@yahoo.com.br. a_gaby@ hotmail.com, aline-strapasson@hotmail.com, otaviofurtado@hotmail.com gaviao@fef.unicamp.br, edison@fef.unicamp.br

${ }^{* *}$ The College at Brockport, State University of New York, Brockport, United States.

E-mail: llieberm @ brockport.edu

Recebido em: 11-08-2016 Aprovado em: 14-08-2017

$\mathrm{DOl}$ http://dx.doi.org/10.22456/1982-8918.66851 (c) (1) (8) Licence 


\section{INTRODUCTION}

Inclusion is considered the right of every person to have good education in regular schools (BLOCK, 2016). Although inclusion is primarily related to children with disability, it has been proposed as an educational reform to meet the needs of all students. The focus of inclusion is the realization of learning and effective social participation with the elimination of barriers in the school environment (AINSCOW; MILES, 2009; BOOTH; AINSCOW, 2002).

In the realm of physical education, several studies have presented major barriers regarding the participation and involvement of students with disability. For example, studies have shown that students with disability associate physical education classes with negative experiences (BREDAHL, 2013), feeling excluded, experiencing limited participation, and even being totally segregated from their peers (ALVES; DUARTE, 2013; BLINDE; MCCALLISTER, 1998; CHICON; MENDES; SÁ, 2011; GOODWIN; WATKINSON, 2000; HAEGELE;SUTHERLAND, 2015; HUTZLER et al., 2002; FRANK et al., 2013; PLACE; HODGE, 2001; RODRIGUES; FERREIRA, 2013; FALKENBACH et al., 2007). Chicon, Mendes and Sá (2011) even described a case in which students with disability were excluded from general physical education classes and had to practice different activities without any clear educational meaning. In other instances, common practices adopted by physical education teachers were to name students with disability as their assistants or to assign them the task of refereeing games played by their peers (RODRIGUES; FERREIRA, 2013).

It is then reasonable to assume this reality is largely associated to failures in physical education teachers training (CHICON; MENDES; SÁ, 2011; FRANK et al., 2013; HAEGELE, SUTHERLAND, 2015; RODRIGUEZ; FERREIRA, 2013; FALKENBACH et al, 2007; MUNSTER, 2013). In fact, Block and Obrusnikova (2007) stated that physical education teachers in general do not feel prepared to teach children with disability. They felt this stemmed from their poor knowledge and lack of practical experience to meet the needs of students with disability. At this point, the initial and continuing education they have received became a key issue, being described as insufficient.

Studies conducted in the Brazilian educational context revealed that physical education teachers were unaware of what may be modified in educational programs to meet students needs (AGUIAR; DUARTE, 2005; FALKENBACH et al., 2007; FIORINI, MANZINI, 2014; MUNSTER, 2013; RAMOS et al., 2013; RODRIGUEZ, FERREIRA, 2013). Among Brazilian physical education teachers, there was no consensus related to the inclusion of all children in regular schools, as many felt that students with more severe disability should be educated in special schools (FRANK et al., 2013; FALKENBACH et al., 2007). The concept of educational inclusion is more connected to the presence of students with disability in schools and less associated to the broader understanding of high quality education for all students that is the key focus currently (BOOTH; AINSCOWN, 2012).

There is a clear need to understand these professionals' concepts of inclusion when considering the inclusion of students with disability in physical education. The understanding of inclusion by Brazilian physical education teachers has not yet been investigated thoroughly and may help to understand the obstacles described in their classes. In addition, it is also important to investigate the barriers experienced by these professionals while trying to include students with disability in physical education classes. Results from these queries may then 
help to foster physical education teachers training. Thus, the purposes of this study were to 1) analyze physical education teachers' concept of inclusion and 2) to determine the positive and negative aspects of inclusion in their classes.

\section{METHOD}

This was a qualitative, descriptive research design. The project was approved by the first author's University's Internal Review Board and before the start of the study all participants signed an informed consent form.

\subsection{Participants}

Eighteen physical education teachers participated in this study (Table 1). All were teaching in public schools of a large city in the state of São Paulo - Brazil; 13 were female and 5 were male, aged between 27 and $56(42.1 \pm 8.1)$ years old, with 4 to $35(16.6 \pm 9.2)$ years of experience in teaching physical education. To be included in this study, teachers were required to have taught physical education for students with and without disability. Teachers who were not working during the training program, for any reason, were excluded from the study.

Table 1 - Participants Characteristics.

\begin{tabular}{|c|c|c|c|c|c|}
\hline Participant & Gender & Age (years) & Experience (years) & Graduated & APE classes \\
\hline P1 & $\mathrm{F}$ & 56 & 35 & 1980 & NO \\
\hline P2 & $\mathrm{F}$ & 48 & 21 & 1986 & NO \\
\hline P3 & $\mathrm{F}$ & 47 & 20 & 1987 & NO \\
\hline P4 & $\mathrm{F}$ & 46 & 25 & 1988 & NO \\
\hline P5 & $\mathrm{F}$ & 45 & 25 & 1988 & NO \\
\hline P6 & $\mathrm{F}$ & 44 & 25 & 1989 & NO \\
\hline P7 & $\mathrm{F}$ & 48 & 20 & 1989 & NO \\
\hline P8 & $\mathrm{F}$ & 47 & 15 & 1989 & YES \\
\hline P9 & $\mathrm{F}$ & 47 & 14 & 1992 & YES \\
\hline P10 & $\mathrm{F}$ & 37 & 14 & 1997 & YES \\
\hline P11 & $\mathrm{F}$ & 36 & 15 & 1998 & YES \\
\hline P12 & $\mathrm{F}$ & 40 & 5 & 1998 & YES \\
\hline P13 & $\mathrm{F}$ & 31 & 4 & 2007 & YES \\
\hline P14 & $M$ & 50 & 25 & 1987 & NO \\
\hline P15 & $M$ & 48 & 23 & 1988 & NO \\
\hline P16 & $M$ & 32 & 4 & 2003 & YES \\
\hline P17 & $M$ & 30 & 5 & 2006 & YES \\
\hline P18 & M & 27 & 5 & 2008 & YES \\
\hline
\end{tabular}

Subtitle: F - female; M - male; Experience - years working as teacher in regular school; Graduated - year the participant graduated in physical education; APE classes - if the participant took adapted physical education classes during initial training. Source: date's research

\subsection{Data collection}

The participants were selected from an adapted physical education training course offered to physical education teachers, regularly teaching in the city's educational system. This 
teachers' training aimed to provide advanced knowledge regarding the inclusion of children with disability in general physical education classes. The concept of inclusion, information about the most common student's disability and respective implication for classes, and possible teaching strategies and adaptations were the themes addressed during the course. Prior to its beginning, the participants were invited to take part in an interview, so that the course syllabus would not interfere in the participant's answers.

An interview guide with five open ended questions was the main tool (Table 1) of this research. This instrument allowed the authors to explore participant's concepts of inclusion in physical education classes, and barriers and facilitators experienced in their pedagogical practice. According to Seidman (1998), the use of interviews is not intended to test hypothesis, to appraise the answer to questions or to assess a given situation. Semi structured interviews should allow the researcher to investigate the respondents' comprehensions of their beliefs about specific concepts or experiences. The goal is to explore the interviewees' perspectives, allowing them to reconstruct their experience based on the topic being addressed (PATTON, 2002; SEIDMAN 1998).

The questions were developed by the first author, who has experience teaching inclusive physical education at the elementary level, conducting adapted physical education training to teachers in continuing education programs, and developing qualitative research. To establish content validity of the interview guide one adapted physical activity faculty member, with more than 20 years of experience in the field, reviewed and provided feedback on the questions. The interview was conducted by the first author. Her previous experience with the theme and the reality of Brazilian schools was central to enable a deeper exploration of the participants' answers.

The interviewer began each interview describing her background as a teacher and researcher and followed by explaining researcher positionality. Positionality is understood as the relationship between the researcher and the group being studied (HAEGELE; SATO; ZHU; AVERY, 2017). In this context, the researcher introduced herself to the participants as an adapted physical education professor at a Brazilian public university, with previous experience in general physical education, which included students with and without disability.

In qualitative research, reflexivity refers to researcher's awareness of their experiences and theoretical influences on the study design, development, and conclusions (ZITOMER: GOODWIN, 2014). During the interview process field notes were taken and identified personal values and judgements that could interfere in the process of data collection and analysis. Field notes were considered in the researchers' reflections on the data and their meaning and also on possible emerging themes.

Table 1 - Interview about inclusion conception

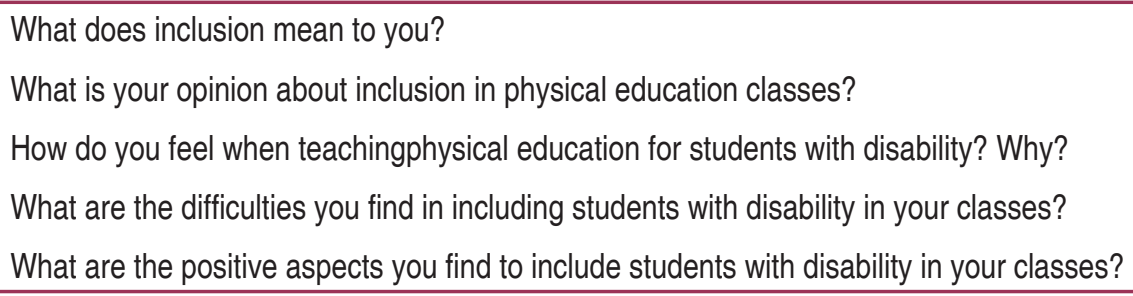




\subsection{Data analysis}

The answers to the interviews were analyzed according to Bardin's (2010) content analysis method, which comprises the categorical analysis technique. The categorical analysis encompasses the recognition and thematic analysis in order to "[...] discover the main meanings that compose communication which occurrence presence or frequency can mean something for the chosen analytical purpose" (BARDIN, 2010, p.131). In this type of analysis the text is separated in units and, then, grouped by similarities in thematic categories. The units are coded according to their contextual meaning and can be distinct in nature and in dimension, represented by words, sentences, or themes (BARDIN, 2010).

The initial themes inference and interpretation were carried out within the context of each participant, with subsequent categorization into larger thematic groups considering all teachers' responses. In this step, the researcher searched for similar themes across all participants. Finally, in-depth analysis of emerging themes within each of the previously identified categories was performed, allowing the identification of subcategories and their interrelations (BARDIN, 2010).

Following this process, thematic categories were interpreted exhaustively. At this point, Bardin (2010) proposes that researchers should explore participants' discourses and its meaning, based on a theoretical framework. Resulting from this process, three distinct and evident thematic categories were established: 1) understanding of inclusion; 2) reality and prospects; and 3) barriers and facilitators (Table 2).

Ilustration 2 - Category and subcategories of analysis.

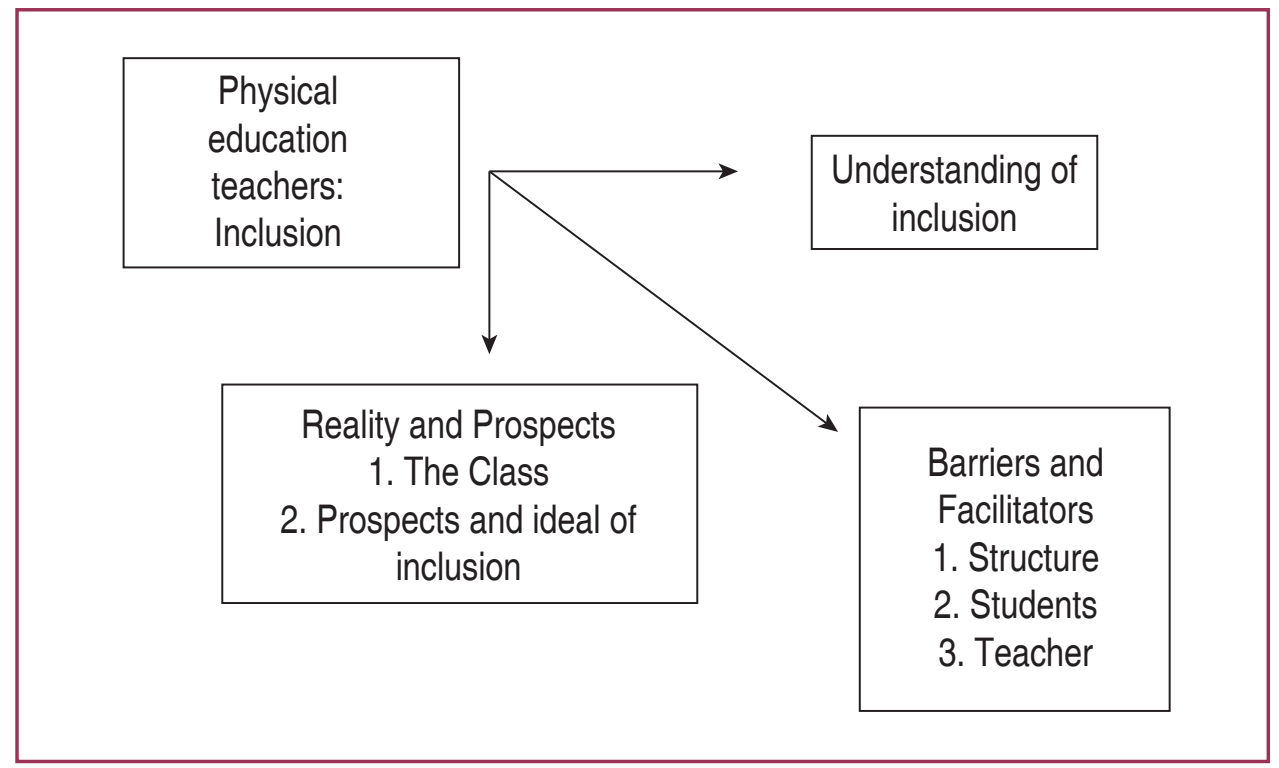

Source: Adapted Bardin (2010)

\section{FINDINGS}

The diverse sample allowed us to confront and reflect on opinions and various experiences of physical education teachers. Those with in depth experience, but without initial training for inclusion, contrasted to teachers with little experience in the profession, but with 
initial training in the adapted physical education area. Thus, it was possible to understand varied beliefs and realities experienced by these professionals during the inclusion process of students with disability in their classes. The study findings revealed strengths and obstacles frequently reported in their work. The results are presented according to the three main categories of analysis and respective subcategories found using (Table 2): 1) understanding of inclusion; 2) reality and prospects; and 3 ) barriers and facilitators.

\subsection{Understanding of inclusion}

for teachers with longer professional practice, without initial training towards inclusion, the concept of inclusion was linked mainly to the terms "disability" and "peer acceptance". Inclusion was seen as the process in which society accepts people with disability, providing conditions and opportunities for their involvement and social participation.

For those who graduated more recently and took classes related to the theme during their initial training, the concept of inclusion was more related to the terms "acceptance", "difference" and "disadvantage". For these teachers, inclusion involved society's acceptance of individual differences, which may or may not be disability-related. At this point, disadvantage means 'the loss presented by person that affects their participation and involvement in various social contexts'. This different position between older and younger teachers shows a transition and expansion of the inclusion concept. Previously, only linked to the person with the disability, it is now being understood and advocated as a right for all students.

One of the main aspects of the inclusion concept in physical education classes is regarded as the student's active participation, meaning their engagement in class activities and their social interaction with classmates. To exemplify, P18 described inclusion as "[...] being able to involve all students in the activity that is going on during classes". In this sense, inclusion meant meeting the educational needs of all students. The concept of disadvantage tended to amplify the teacher's attention to the group as a whole. For P3, inclusion "[...] is actually not only about the disabled. [...]. Very often there is this very shy child... and you don't even interact with him/her [...]". In this sense, P16 stated that "It is not only the student with a physical, motor, or intellectual disability, but there is also the student with a learning disability or the student with an emotional disorder."

\subsection{Reality and prospects}

the theme of Reality and Prospects revealed two themes. One was The Class, and the second one was Prospects and ideal of inclusion. The following are the findings of what was generated by the teachers interviewed.

\subsubsection{The class}

In their classes, physical education teachers tried to promote inclusion by adapting the proposed activities for their students with disability. Determining the necessary adjustments was a gradual process, where students with disability had active participation. P5 acknowledged that initially there was an adaptation process of both the student with disabilityto the group 
(i.e., teacher and peers)and the teacher to the specific characteristics of this student, being necessary to observe :

[...]what the children could do together with others and how others could help this child that was coming to the group.But then the child meets their peers, then joins the group, and we make adaptations.We plan games in a way that he/she can participate in, with or without help, having support as needed.So,we think about the possibilities, we use our intuition, we think about what works, and what we think we can do. (P5).

Another important aspect was the recognition of the need of adaptations not only to students with disability, but also to those with different characteristics and peculiarities, as P1 says: "I have obese students. I have shy students, introvert students." P10 adds that "[...] independent of being disabled or not. There is a girl whose mother has never let her to walk on a low wall... it is very different to see her doing some activity she was encouraged to do, she had fun with [...]." In this regard, it is also important to point out that students with disability should also take advantage of their class learning goals. Adaptations must promote students' development, by providing the appropriate challenges to meet their skills and abilities.

However, physical education teachers recognized that students with disability participation was still limited. P18 reported that: "I think it's important that they participate but we can't always make it happen. I can get him to participate in the stretching, one or another activity." Due to several factors, such as 1) lack of knowledge about possible adaptations, 2) the number of students per class, and 3) the diversity of unrelated educational needs related to the disability, participants found it difficult to promote the involvement of the student throughout the class. Teachers stated that often they proposed separate activities for students with disability mostly focusing on gross motor skills. These activities do not share the same educational goals as their peers, as reported by P5:

If it does not work [...] then, it's Ok.Shortly, we play just the two of us.I do that with some kids.For example, in a dodge ball game, in which the student with Down syndrome does not play, after the game is overl play for a while with her... bouncing, rolling the ball [...]

According to participants, team sports were very challenging activities when they tried to promote inclusion. One obstacle concerns was the lack of basic knowledge to appropriately adjust games in order to meet educational needs of students with and without disability playing together. Here again, teachers reaffirmed the common practice of proposing separate activities for students with disability. In this matter P17 says: "[...] in the game he will not be able to play along with everybody. So, I'll think of a plan B for him." Also, P16 described that "[...] I had a hard time teaching team sports. What I could do was not exactly what I had planned for that class. Usually, I ended up spending more time in sport skills."

\subsubsection{Prospects and ideal of inclusion}

The prospects and ideals of inclusion themes are related both to the educational preparation for inclusion and its implementation during classes. The preparation for inclusion ideally would offer continuing education opportunities to teachers, who could then acquire knowledge about different types of disability and the possible implications on physical education practices. They would also learn ways to adjust curriculum and instructional methods. 
Additionally, continuing education should provide practical experiences and opportunities for teachers to share and discuss their own cases of inclusion.

The presence of a teacher assistant and having classes with fewer students were also identified to be ideal conditions for inclusion. Moreover, the presence of only one student with a disability per class was mentioned to be a problem when teaching content such as team sports. In this situation, teachers suggested that classes should be more homogeneous, so students would play games and adapted sports with their peers with similar disability. In this matter, P1 reported: "I have a hard time with only one wheelchair student. If I had ten wheelchair students... they could play football[...] handball, volleyball. I would do anything."

\subsection{Barriers and facilitators}

The theme Barriers and Facilitators revealed the sub-themes structure, students and teachers.

\subsubsection{Structure}

Political, organizational and physical structure in the educational system were seen as major factors for success in the process of inclusion. Regarding the organizational aspect, the main obstacles were 1)the inadequate working conditions, with constant change of school 2) the lack of time for class preparation and, 3) the number of students per class. Participants also shared their frustration about schools' facilities, specifically the lack of accessible and adequate spaces for practice, leading to the need to use adapted spaces. Thus, P1 described that "I have to stay in a place where students stay during their break, so I have to leave before it starts [...]. I have to leave 20 or 30 minutes before the class has finished. Then I go to another place, an area in the parking lot"

The scarcity of adapted material was also a barrier shared by physical education teachers. In this respect, P16 raised a relevant question by stating that adapted material for physical education classes should always be available in order to facilitate including students with disability.P16 stated:

[...] think that a lot can be adapted. But I don't think it's fair that I have to adapt materials all the time. If there's no ball, let's play with a ball made of socks. Let's play with newspaper. I think my student has the right to have a good wheelchair, if necessary. They must have a goalball ball, for example. We usually wrap a plastic bag around a basketball, but l'd rather have a goalball ball with bells inside.

Generally, these obstacles are seen by physical education teachers as a consequence of inadequate educational policies towards high quality educational inclusion. So far, policies ensure only the access of students with disability to schools, however, without providing ideal conditions for their learning and social interaction with peers. For P3: "[...] I actually do not think we evolved in quality. We do have more children in schools. But what about quality?"

The presence of an assistant teacher during physical education classes was indicated as a facilitator aspect pertaining to the school structures. Although this was not the case for most participants of the study, some described the experience of "double teaching", when a teacher spends part of their working hours helping another teacher in their class or when two 
teachers teach their classes in the same space with similar activities. In this practice, one of the teachers is in charge of the activities, while the other becomes the assistant helping to promote an inclusive class. P17 describes that the ideal would be:

[...] if we had a permanent assistant or a paraeducator to help us during classes. $[\ldots]$ sometimes we do double teaching [...]so, at least one teacher leads the class, while the other assist in whatever is needed.

\subsubsection{Students}

The acceptance of students with disability by their peers was described both a facilitator and an obstacle to professional performance. However, this acceptance was not so clear, especially among adolescents and in classes where the student with disability recently enrolled. Here, P18 reported that: "I think that with older students we have the rejection issue. To me, it seems that as they get older the acceptance is less likely."

Another major obstacle to inclusion was the educational demands unrelated to the presence of students with disability, such as students' behavioral problems, lack of interest, emotional problems, and fear of engaging in physical activities. P17 states that: "[...] the biggest issue[...]when thinking about the disabled is the number of students with other issues". Thus, meeting different educational needs, while resolving conflicts in the group prevented teachers from fostering more participation of students with disability throughout the class.

The type of the student's disability was also cited as an obstacle to their inclusive process. For physical education teachers who participated in this study, students with autism were considered the most difficult to deal with during classes because of their unique characteristic of social isolation. Another major obstacle referred to the students with disability resistance to participate in activities adapted for their needs.P18 said that: "[...] she did not like when activities were changed to accommodate her".

\subsubsection{Teacher}

The participants of this study, referred to the lack of knowledge about student's disability as a major obstacle to inclusion. This resulted in feelings of personal insecurity and negatively impacted on the choice of appropriate methods and teaching strategies. P1 says: "[...] I am unaware of students' disability [...] only in April I was given some explanation about the disability." For $16.7 \%$ of the participants, the lack of knowledge about the students' diagnosis and its implications to practice were related to their perception of inability to include the student with the disability. Participants emphatically suggested the importance of a continuing education, in which they could share experiences with other teachers and try to find ways to effectively adapt activities to include diverse students.

Nonetheless, for $83.3 \%$ of the teachers this unfamiliarity was not predominant in regard to being able to work with students with disability. Most participants stated they felt able or partly able to promote inclusion. For those, teaching students with disability made them seek strategies and ways to promote learning and participation. In this context, inclusion was understood as a process in which teachers discovered what can be done, and learn along with students with 
disability, regardless of their condition.P3 says: "I may not know how to do the it right, but I'm always learning."

The facilitators to inclusive physical education were linked to teachers' previous experiences in working with students with disability, which provided confidence to propose adjustments when needed. Experiences should be offered from the initial professional preparation program, when real life educational practices would provide face-to-face interactions between children with disability and the future teacher. For P5 it is important that: "Here [during the continuing education course] we do the activity and have fun with a wheelchair, but it's one thing. The other is when we are in the child's environment."

\section{DISCUSSION}

In some countries, inclusive education is still considered as care for children with disability in regular school. However, there is an increasing recognition of this kind of education as a continuous process to improve participation and learning for all students and not only for those with disability. By assuming the diversity in classrooms, students with disability are no longer the sole focus in the process to accommodate the needs of all children (AINSCOWN; MILES, 2009; BOOTH; AINSCOW, 2002). Inclusion is best understood through a biopsychosocial model, in which the barriers to learning and participation result not only from individual characteristics, but also from its interaction with the environment and activity (SHERRIL, 2004; BOOTH; AINSCOWN, 2002).

Based on physical education teachers' views, the results of this study demonstrated that inclusion is still a theme under construction. Teachers who graduated prior to 1990 and received no training on the subject, still link the inclusion concept only to the participation of students with disability in regular schools. On the other hand, teachers with recent training showed a broader understanding of inclusion, which is in accordance to the current trend of being seen as a process to improve the quality of education for all, by eliminating the barriers presented to any student. Students who were not in the focus of concern to physical educators, with the process of inclusion, can now benefit from physical education classes, a major shift in thinking from earlier years.

We have presented here an evolution in the concept of inclusion, revealing a positive advance compared to previous Brazilian studies with physical education teachers (AGUIAR; DUARTE, 2005; FALKENBACH et al, 2007; FIORINI, MANZINI, 2014; MUNSTER, 2013; RAMOS et al, 2013; RODRIGUEZ, FERREIRA, 2013). The participants of this study recognized the need to adapt classes not only due to the presence of students with disability, but also for other students, such as those with obesity or behavioral disorders, or even for those who are shy. This understanding of inclusion tends to improve the quality of classes. Diversity is acknowledged among students and requires adaptations that are accepted for successful participation and learning of all students (BOOTH; AINSCOWN, 2002).

Despite teachers' belief on the inclusive process to their classes, it is interesting to note that there are differences in its implementation. While some participants believed that inclusion meant to ensure full participation of students with disability in all activities, along with their classmates, others understood that providing students with disability separate activities, in specific situations, also represented the fulfillment of their individual educational needs. In this 
sense, Hodge, Lieberman and Murata (2012)supported the idea of having all students together, but also propose that children with disability should be involved in separated activities, if a separate setting is agreed upon in their individual educational meeting. If the educational team supported a separate setting in physical education for a student then they could still meet their goals and objectives in this setting.

However, it is important to emphasize that the reality described by the participants of this work showed the participation of students with disability in segregated activities, without clear educational goals or relation to the content of the main class. Largely, the segregated activities occurred when teachers were not able to make adaptations to the activity so student with disability could be included. In this situation, teachers reported to propose activities only for student's fun and enjoyment. The limited participation of student with a disability in physical education classes has been described by several other authors (ALVES; DUARTE, 2013; BLINDE; MCCALLISTER, 1998, GOODWIN, 2001, GOODWIN;WATKINSON, 2000, HUTZLER et al., 2002; PLACE; HODGE, 2001) as well as activities without educational purposes (FALKENBACH et al. 2007; RODRIGUES;FERREIRA, 2013), demonstrating how challenging it is to promote inclusion in schools.

Physical education teachers reported difficulty in adapting team sports when students with disability were present. Mostly, the segregation of these students happened in this sort of activity. At this point, teachers mentioned lack of knowledge of how to adapt activities or games in order to meet the demands and needs of both students with and without disability. When used, severe modifications may change the nature of the game or the challenge of the game, which make peers without disability dissatisfied with the activity and even resent having peers with disability in their physical education class (BLOCK, 2007, HODGE; LIEBERMAN; MURATA, 2012).

Hence, it is important to reflect on the physical education curriculum contents being structured for students with disability. The typical physical education class has its basic foundation in the concepts of skills and performance, that are socially created and based on the normal paradigm (BARTON, 1993; EVANS, 2004; FITZGERALD, 2005). In this context, adapted physical education scholars have questioned the basic knowledge and values for inclusive practices. If we consider the way sports are taught in schools, a student with a disability will rarely succeed in physical education classes (BARTON, 1993; BRITTAIN, 2004a, 2004b; EVANS, 2004; FITZGERALD, 2005; LIEBERMAN;HOUSTON-WILSON, 2018).

Schools and physical education classes are deemed to be the main places of involvement and learning sports during childhood. In the case of children with disability, their exclusion from these activities or their partial involvement in occasional adapted practices precludes their understanding about sports already developed for their specific disability. This fact helps to limit their involvement in sport activities outside the school environment, where the goal could be to succeed in sports, such as the ones included in the Paralympic Games. Similar to students without disability, experiences with the adapted sport and its various manifestations should be seen as a right of students with disability. It is then important to reflection the inclusion of adapted sport as a part of the physical education curriculum.

As a solution, teachers suggested that students with disability get involved in adapted sports designed for those with similar conditions. This type of practice can be seen as a step back, by stimulating segregation among students, however, it can further be recognized as a way 
to meet specific needs of children and adolescents with disability, where learning opportunities and involvement with team sports will be enabled.

The insertion of sports such as goalball, sitting volleyball, and boccia should not necessarily be restricted to students with disability and has been shown to increase disability awareness and positively impact the attitudes of students without disability toward the inclusion of children with disability in the physical education setting (BORGMANN; ALMEIDA, 2015;MCKAY; BLOCK; PARK, 2015).This approach could improve the quality of education for students with and without disability.

Another relevant aspect to be discussed is the observed relationship between teachers' perception of their ability to include and their understanding of inclusion as a learning process. Thus, those participants who reported feeling able to promote inclusion described it as a process of searching, along with students to be included, for ways and solutions that may be more conducive to learning and participation with the class. Teachers expressed the need for trial and error especially since they did not know the specifics of their students' disability. Getting to know each student individually helped teachers to create lessons that matched their educational needs.

Nonetheless, the identification and understanding of the student's disability can bean important factor for teacher's lesson preparation. In some cases the students health issues may have been influenced by physical activity practices. Albeit this knowledge base should ideally be addressed during graduate courses, it has to be understood only as a starting point for structuring the process of inclusion. According to Sherril (2004), meeting students' educational needs for tackling the challenges of schools relies on the identification and understanding of their relationship to the environment and the task.

In this study, physical education teachers indicated a number of barriers to inclusion. Proper working conditions were not yet experienced, such as accessible spaces and adapted material. The students with disability acceptance by their non-disabled peers was also a major obstacle that must be resolved. Another important barrier related to the lack of opportunity for teachers to work continuously with the same group of students along the years and also the high number of students per class. In order to respond to all these matters, participants highlighted the need of assistant teachers, the reduction in the number of students per class, opportunities to exchange experiences with other teachers, and institutional support. Thus, current inclusive public policies only ensure students with disability access to schools, however, the quality of teaching needs to be improved.

The presence of an assistant teacher in educational settings has already proven to be a useful strategy to promote inclusion (BLOCK; OBRUSNIKOVA, 2007; LIEBERMAN;CONROY, 2013).These authors proposed that several professionals can provide support for teachers during physical education classes, such as special educators (responsible for providing general assistance to all school teachers), adapted physical education specialists (able to provide guidance to schools from the same region), or even assistant teachers or paraeducators without specific training in the area (to support the needs of students with severe disability).

Although the presence of this support can be beneficial for the inclusion of students with disability (BLOCK; OBRUSNIKOVA, 2007), some aspects should be considered. The assistant teacher supporting during class should not affect or restrict the interaction of students 
with disability with other students or teacher. The instruction of an adapted physical education specialist, even when absent from classes, is considered to positively influence both learning and participation of students with and without disability(BLOCK; OBRUSNIKOVA, 2007). These professionals can instruct physical education teachers to make curricular and pedagogical changes, according to the needs of their students.

Our results are in line with previous studies that also indicated major flaws in the inclusion of students with disability in physical education classes (ALVES; DUARTE, 2013; CHICON; MENDES; SÁ, 2011; FRANK et al, 2013; FALKENBACH et al, 2007; RODRIGUES; FERREIRA, 2013). Moreover, the findings of the present study advance this knowledge base by revealing factors related to the Brazilian educational context, such as the challenge to carry on longer inclusive education projects, the issue of having a high number of students per class, and the lack of supportive inclusion policies. This research further highlights that inclusion in physical education classes is currently an art of improvisation, mainly due to inadequate environmental conditions, materials, equipment, and pedagogical knowledge.

Finally, after exploring the participants concept of inclusion and how it can be implemented in practice, a problematic paradox became clear. While they recognized the legal right and the educational value of including students with disability in the mainstream classes, they also pointed out how difficult it is to make the needed modifications in a curriculum specifically designed for students without disability. Thus, the present study brings a contemporary reflection on the inclusion of students with disability in physical education classes in a Brazilian context. Although it is impossible to draw any conclusion at this time, it is very important to have a clear and structured concept of inclusion and to foster the promotion of equality among students. More relevant, not only equal opportunities to all should be sought, but, primarily, ideal opportunities that take into consideration the special needs of any single student (BARTON, 1993).

\section{REFERENCES}

AGUIAR, João Serapião; DUARTE, Edison. Educação Inclusiva: um estudo na área da Educação Física. Revista Brasileira Educação Especial, v.11, n.2, p.223-240, 2005.

AINSCOW, Mel; MILES, Susie. Developing Inclusive Education Systems: how we can movie Policies Forward? Manchester, 2009. Available from: <http://www.ibe.unesco.org/fileadmin/user upload/COPs/News documents/2009/0907Beirut/Developinglnclusive Education Systems.pdf>. Accessed: 22 jul. 2015.

ALVES, Maria Luíza Tanure; DUARTE, Edison. A exclusão nas aulas de Educação Física:

fatores associados com participação de alunos com deficiência. Movimento, v. 19, n. 1, p. 117-137, jan./mar. 2013.

BARDIN, Laurence Análise de Conteúdo. 4. ed. Lisboa: Edições 70, 2010.

BARTON, Len. Disability, Emporwement and Physical Education. In: EVANS, J. (Ed.). Equality, education and Physical education. London: Falmer Press, 1993. p. 28-43. 
BLINDE, Elaine M.; MCCALLISTER, Sarah G.; Listening to the Voices of students with Physical Disability. Journal of Physical Education, Recreation and Dance, v. 69, n.6, p. 64-68, 1998.

BLOCK, Martin E. A teacher's guide to including students with disability in general physical education. 2. ed. Baltimore: Brookes, 2000.

BLOCK, Martin E.; OBRUSNIKOVA, Iva. Inclusion in Physical Education: a Review of Literature from 1995-2005. Adapted Physical activity Quartely, v. 24, p. 103-124, 2007.

BOOTH, Tony; AINSCOW, Mel. Index for Inclusion: developing learning and participation in schools. Bristol: Centre for Studies in Inclusive Education, 2002. Available from: <http://www.eenet.org.uk/ resources/docs/Index\%20English.pdf>. Accessed: 22 Jul. 2015.

BORGMANN, Thiago; ALMEIDA, José Júlio Gavião. Esporte paralímpico na escola: revisão bibliográfica. Movimento, v.21, n.1, p. 49-64, 2015.

BREDAHL, Anne-Mette. Sitting and Watching the Others Being Active: the Experienced Difficulties in PE When Having a Disability. Adapted Physical Activity Quartely, v.30, p. 40-58, 2013.

BRITTAIN, lan. Perceptions of disability and their impact upon involvement in sport for people with disability at all levels. Journal of Sport \& Social Issues, v.28, n.4, p. 429-452, 2004a.

BRITTAIN, lan. The Role of Schools in Constructing Self-perceptions of Sport and Physical Education in Relation to People with Disability. Sport, Education and Society, v. 9, n.1, p. 75-94, 2004b.

CHICON, José Francisco. Inclusão e Exclusão no Contexto da Educação Física Escolar. Movimento, v.14, n.1, p. 13-38, 2008.

CHICON, José Francisco; MENDES, Kamo; SÁ, Maria das Graças Carvalho Silva. Educação Física e inclusão: a experiência na Escola Azul. Movimento, v. 17, p.185-202, 2011.

EVANS, John. Making a difference? Education and 'ability'in physical education. European Physical Education Review, v.10, n.1, p. 95-108, 2004.

FALKENBACH, Atos Prinz et al. A inclusão de crianças com necessidades especiais nas aulas de Educação Física na educação infantil. Movimento, v.13, n. 2, p.37-53, 2007.

FIORINI, Maria Luíza Salzani; MANZINI, Eduardo José. Inclusão de Alunos com Deficiência na Aula de Educação Física: Identificando Dificuldades, Ações e Conteúdos para prover a Formação de Professores. Revista Brasileira de Educação especial, v. 20, p.387-404, 2014.

FITZGERALD, Hayley. Still Feeling like a Spare piece of Luggage? Embodied experiences of (dis)ability in physical education and school sport. Physical Education and Sport Pedagogy, v.10, n.1, p. 41-59, 2005.

FRANK, Robsont et al. Significação do Conceito de Inclusão Escolar para Professores de Educação Física. Conexões, v. 11, n. 3, p. 86-113, 2013.

GOODWIN, Donna L.; WATKINSON, E. Jane. Inclusive Physical Education from the Perspective of Students with Physical Disability. Adapted Physical Activity Quartely, v. 17, p. 144-163, 2000.

HAEGELE, Justin A.; SUTHERLAND, Sue. Perspectives of Students with Disability toward Physical Education: a Qualitative Inquiry. Quest, v.67, p. 255-273, 2015.

HAEGELE, Justin et al. Physical Education Experiences at Residential Schools for Students Who are Blind: 
HODGE, Samuel; LIEBERMAN, Lauren; MURATA, Nathan. Essentials of Teaching Adapted Physical Education. Arizona: Holcomb Hathaway, 2012.

HUTZLER, Yesahayu et al. Perspectives of Children with Disability on Inclusion and Empowerment: Supporting and Limiting factors. Adapted Physical Activity Quartely, v. 19, p. 300-317, 2002.

LIEBERMAN, Lauren J.; CONROY, Paula. Training of Paraeducators for Physical Education for Children with Visual Impairments. Journal of Visual Impairments and Blindness, v.107, n.1, p.17-28, 2013.

LIEBERMAN, Lauren J.; HOUSTON-WILSON, Cathy. Strategies for Inclusion: Physical education for everyone. Champaign, Human Kinetics, 2018.

MCKAY, Cathy; BLOCK, Martin E.; PARK, Jung Yeon. The Impact of Paralympic School Day on Student Attitudes Toward Inclusion in Physical Education. Adapted Physical Activity Quarterly, v. 32, n.4, p.331-348, 2015.

MUNSTER, Mey de Abreu. Inclusão de Estudantes com Deficiências em Programas de Educação Física: Adaptações Curriculares e Metodológicas. Revista da Sobama, v. 14, n. 2, p. 27-34, jul./dez. 2013.

PATTON, Michael Quinn. Qualitative Research and Evaluative Methods. 3. ed. California: Sage, 2002.

PLACE, Kimberly; HODGE, Samuel. Social Inclusion of Students with Psysical Disability in General Physical Education: A Behavioral Analyses. Adapted Physical Activity Quartely, v. 18, p. 389-404, 2001.

RAMOS, Valmor et al. Autopercepção de competência pedagógica de professores de Educação Física no ensino inclusivo. Revista Brasileira de Ciência e Movimento, v. 21, n.2, p. 123-134, 2013.

RODRIGUES, Irene Elias; FERREIRA, Samara de Farias Fernandes. A Prática Pedagógica do Professor de Educação Física em um Ambiente Escolar Inclusivo. Revista da Sobama, v.14, p 33-38, 2013.

SEIDMAN, I. Interviewing as Qualitative Research: a Guide for Researchers in Education and the Social Sciences. 2. ed. New York: Teachers College, 1998.

SHERRIL, Claudine. Adapted Physical Activity, Recreation and Sport: Cross Disciplinary and Lifespan. New York: McGrawHill, 2004.

ZITOMER, M.; GOODWIN, D. L. Gauging the Quality of Qualitative Research in Adapted Physical Activity. Adapted Physical Activity Quarterly, v.31, p.192-218, 2014. 
